Corrigendum

\title{
Corrigendum to "Proteases from Canavalia ensiformis: Active and Thermostable Enzymes with Potential of Application in Biotechnology"
}

\author{
Rayane Natashe Gonçalves, Suellen Duarte Gozzini Barbosa, \\ and Raquel Elisa da Silva-López
}

Department of Natural Products, Farmanguinhos, Oswaldo Cruz Institute (FIOCRUZ), Avenida Brasil 4365, 21045-900 Rio de Janeiro, RJ, Brazil

Correspondence should be addressed to Raquel Elisa da Silva-López; rlopez@far.fiocruz.br

Received 26 September 2016; Accepted 29 September 2016

Copyright (C) 2016 Rayane Natashe Gonçalves et al. This is an open access article distributed under the Creative Commons Attribution License, which permits unrestricted use, distribution, and reproduction in any medium, provided the original work is properly cited.

In the article titled "Proteases from Canavalia ensiformis: Active and Thermostable Enzymes with Potential of Application in Biotechnology" [1], the name of the first author was given incorrectly as Rayane Natshe Gonçalves. The author's name should have been written as Rayane Natashe Gonçalves. The revised authors' list is shown above.

\section{References}

[1] R. N. Gonçalves, S. D. G. Barbosa, and R. E. da SilvaLópez, "Proteases from Canavalia ensiformis: active and thermostable enzymes with potential of application in biotechnology," Biotechnology Research International, vol. 2016, Article ID 3427098, 11 pages, 2016. 

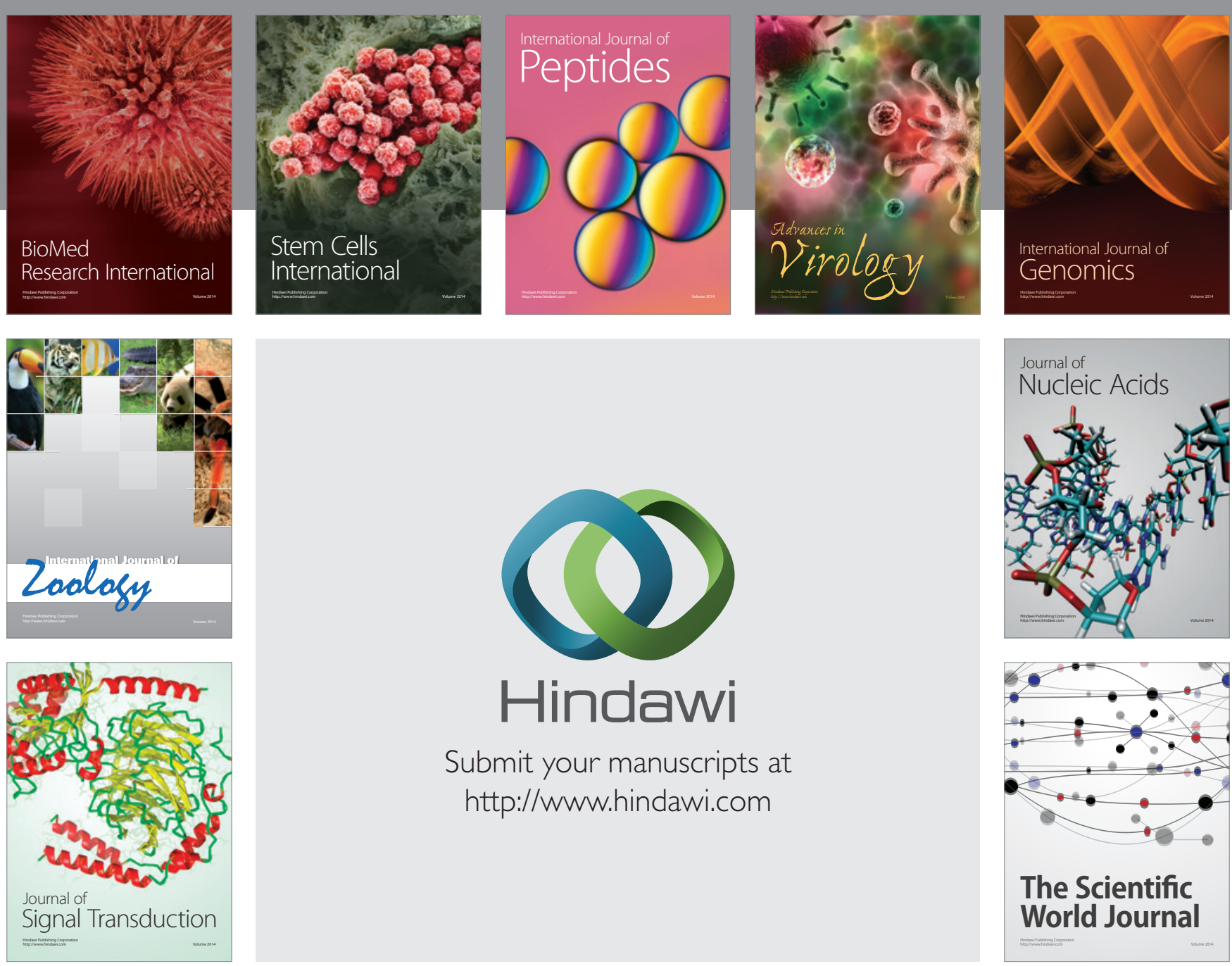

Submit your manuscripts at

http://www.hindawi.com
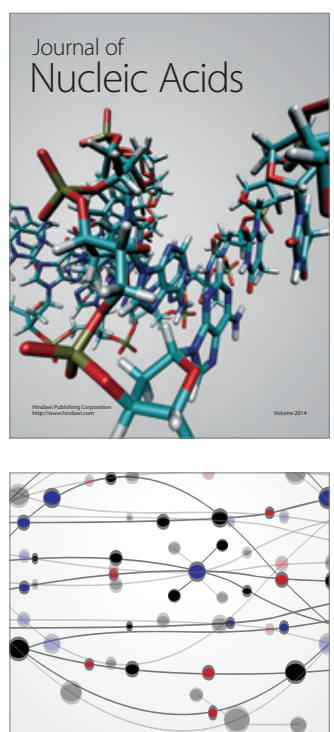

The Scientific World Journal
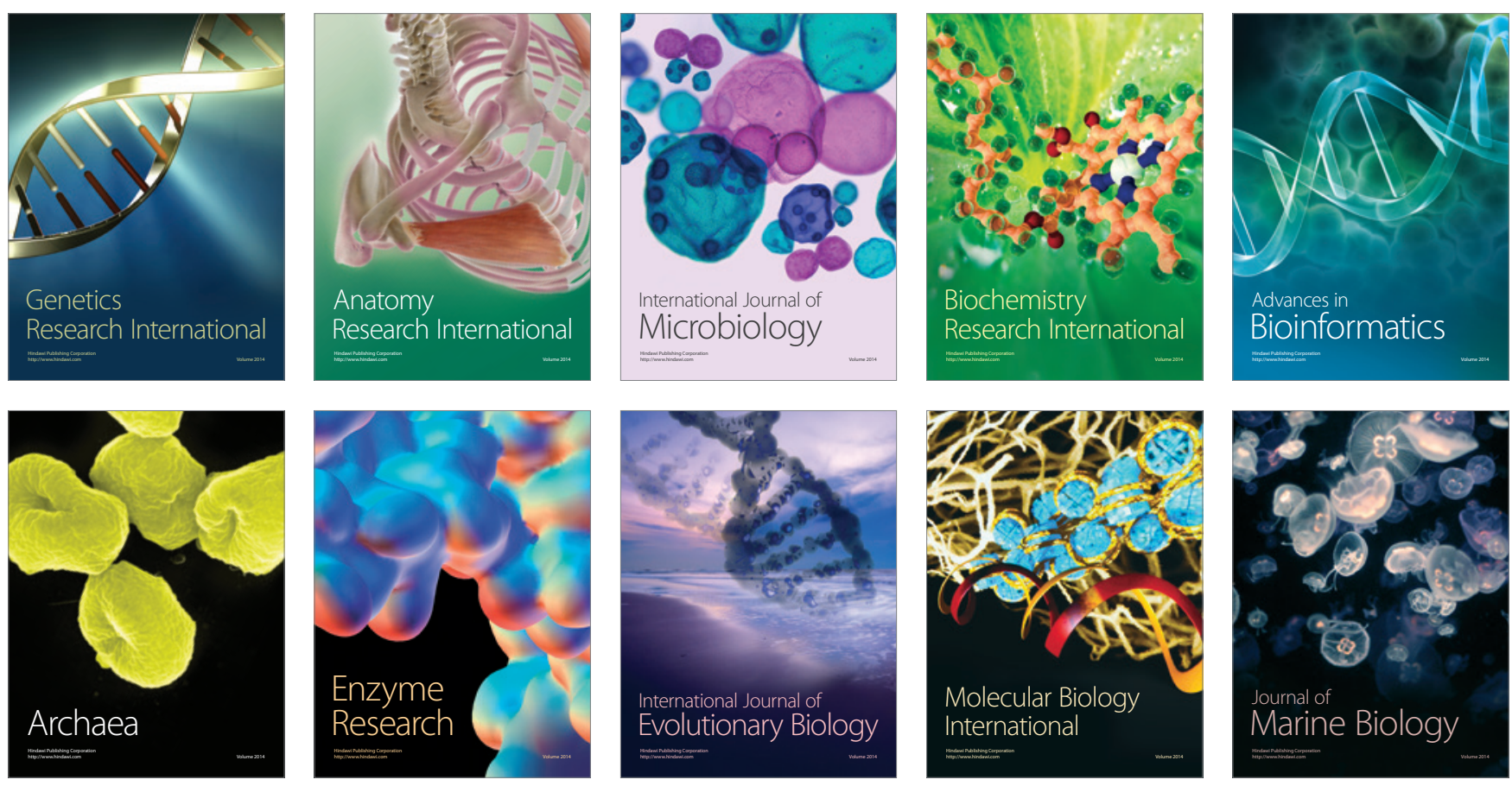